\title{
一総 説
}

食肉の需給に関する世界の動向

永 村 武 美

農林水産省畜産局，千代田区 100

\section{Recent Trend on Meat Supply and Demand in the World}

\author{
Takemi Nagamura
}

Livestock Industry Bureau, MAFF Chiyoda 100

食肉に限らず，世界の農産物の需給動向安的確に把握 する目的は，特定の国，機関，乙して個別の産業等によ り千差万別であると思ら。

家畜の飼養頭数, 品種別の頭数, そして食肉の生産量 等に関する統計值の羅列とそれぞれの数值の解积論もそ れなりの意義があるうが, 本稿では，その種の記述は極 力さけることにしたい.

農産物需給の動向をより正確に把握寸万目的艺大去く 分ければ、二つあると思われる。

一つは，国連のFAO の立場に代表光れるが，特定の 物資が不足する地域あるいは国に対して，援助物凟とし てあるいは生産振興計面の实施等によりその不足分を充 足するための基礎資料としての役割であり，今一つは， 農库物の貿易が，国全体の経済あるいは食料の確保とい ら観点から，極めて重要な位置を占めるような国にとっ て必要な, 輸入あるいは輸出相手国の需給が, 自国の利 益に対して与えるインパタトの程度を知るための基礎資 料としての役割である.

前者については，基本的に FAOに住せて的りばよい というかけではないが，权稿の目的とするここるではな W.

本稿性，後者の立場に立つものである，要するに，わ が国の食肉需給にとって，此界の食肉需給がいかなる ンパクトを有し，しかも最近の情勢の特幑性何かという ととを，本会会冒の大半を点めると思われる研究者の方 々に理解していただくことが本稿のねらいである。

日細会堑，51 (9)：607-625

\section{1. 我が国の食肉需給}

将界の主要な食肉といえば，通常，牛肉，羊肉及び山 羊肉，豚肉，そして家きん肉の四種類を意味するが，加 が国の食肉需給では，これに馬肉を加えている.

これらの食肉の需給について，最近数力年の数值完示 したのが夜てである。

表 1 によると，牛肉の需要墨の䄪 $30 \%$, 豚肉の場含，

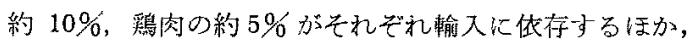
馬肉と羊肉比ついてはほぼ全需要量を輸入に依存してい ることが判る。

次いてここれらの食肉の输入相手国别の輸入量学 2 に 示声.

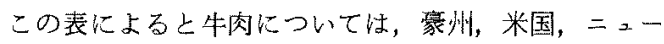
ジーランドの三力国で総輸入量の 95\%以上它力バーす るが，虾でも聚州は最大の供給国として，また米国は， 牛肉を「日米貲易不均衡のシンボル」として把える国と して，われわれが最も神経を使う国である。

脉肉については，力ナダ，米国，デンマータ及び台湾 が主要な輸入相手国でありこの4力国で総輸入量の約 90\%をカバーしている.

この量の多夏恃ともが，豚肉の輸出に刘して，非常に 力走入れているのがデンマ一クと考齐てよいと思う。と いうのは，米国やカナダは，真の意昧で彔肉の輸出国之 は云え始が，デンマークの場會は，国内生産量の約70\% 以上をぶーコンや任誌，そして部分肉として輸比するの 
永 村

茂 1。加が国の食肉需給動向（枝肉ぐース）

\begin{tabular}{|c|c|c|c|c|c|c|c|}
\hline 年度 & 区 分 & 肉 & 肉 & 肉 & 闪 & 肉 & 合 \\
\hline \multirow{5}{*}{45} & 生㦃量 & 282,072 & $778,636^{\vee V}$ & $10,722^{ト ン}$ & $936^{12}$ & 496,451 & $1,568,817$ \\
\hline & 粭出量 & 20 & 24 & 0 & 0 & 755 & 803 \\
\hline & 輸 入量 & 37,566 & 23,826 & 54,789 & 191,926 & 11,903 & 320,010 \\
\hline & 計 & 319,618 & 802,438 & 65,511 & 192,858 & 507,599 & $1,888,024$ \\
\hline & 指 数 & 74.9 (17) & $65.1(43)$ & $78.6(3)$ & $66.2(10)$ & $64.8(27)$ & $67.0(100)$ \\
\hline \multirow{5}{*}{46} & 生産量 & 301,545 & 848,756 & 10,048 & 681 & 564,241 & $1,725,271$ \\
\hline & 輸出量 & 23 & 17 & 8 & 0 & 217 & 265 \\
\hline & 輸 入 量 & 71,287 & 40,646 & 67,209 & 298,190 & 30,127 & 507,459 \\
\hline & _ 計 & 372,809 & 889,385 & 77,249 & 298,871 & 594,151 & $2,232,465$ \\
\hline & 指 数 & $87.4(17)$ & $72.2(40)$ & $92.7(3)$ & $102.6(13)$ & $75.8(27)$ & $79.3(100)$ \\
\hline \multirow{5}{*}{47} & 生産量 & 309,911 & 905,675 & 6,203 & 615 & 636,621 & $1,858,395$ \\
\hline & 輸出量 & 27 & 9 & 0 & 0 & 754 & 790 \\
\hline & 愉 入 量 & 87,569 & 119,701 & 69,998 & 301,240 & 28,880 & 607,388 \\
\hline & 計 & 397,453 & $1,025,367$ & 76,201 & 301,855 & 664,747 & $2,465,623$ \\
\hline & 指 数 & $93.2(16)$ & $83.2(42)$ & $91.5(3)$ & $103.6(12)$ & $84.8 \quad(27)$ & $87.5(100)$ \\
\hline \multirow{5}{*}{48} & 生産量 & 235,492 & $1,000,100$ & 4,210 & 460 & 695,184 & $1,935,446$ \\
\hline & 輸出量 & 23 & 4 & 0 & 0 & 1,361 & 1,388 \\
\hline & 輸入量 & 194,546 & 162,221 & 92,034 & 243,110 & 26,493 & 718,404 \\
\hline & 計 & 430,015 & $1,162,317$ & 96,244 & 243,570 & 720,316 & $2,652,462$ \\
\hline & 指 数 & $100.8(16)$ & $94.4(44)$ & 115.6 (4) & $83.6(9)$ & $91.9(27)$ & $94.2(100)$ \\
\hline \multirow{5}{*}{49} & 生産量 & 353,551 & $1,095,206$ & 4,455 & 371 & 725,579 & $2,179,162$ \\
\hline & 輸出量 & 9 & 21 & 383 & 0 & 2,418 & 2,831 \\
\hline & 輸入 量 & 39,520 & 70,659 & 68,491 & 174,650 & 20,617 & 373,937 \\
\hline & 計 & 393,062 & $1,165,844$ & 72,563 & 175,021 & 743,778 & $2,550,268$ \\
\hline & 指 数 & $92.1(15)$ & $94.6(46)$ & $87.1(3)$ & $60.1(7)$ & $94.9(29)$ & $90.5(100)$ \\
\hline \multirow{5}{*}{50} & 生産舅 & 335,448 & $1,023,496$ & 5,577 & 236 & 758,923 & $2,123,680$ \\
\hline & 輸 出量 & & & 0 & 0 & 3,204 & 3,216 \\
\hline & 輸 入 鵠 & 91,160 & 208,379 & 77,712 & 291,066 & 27,943 & 696,260 \\
\hline & 計 & 426,599 & $1,231,872$ & 83,289 & 291,302 & 783,662 & $2,816,724$ \\
\hline & 指_数 & $100.0(15)$ & 100.0 & $100.0(3)$ & $100.0(10)$ & $100.0(28)$ & $100.0(100)$ \\
\hline \multirow{5}{*}{51} & 生颜 量 & 309,028 & $1,095,747$ & 6,211 & 147 & 839,623 & $2,250,756$ \\
\hline & 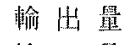 & 14 & 1 & 0 & 0 & 2,446 & 2,461 \\
\hline & 輸 又琵 & 133,611 & 186,723 & 81,671 & 278,208 & 39,642 & 719,855 \\
\hline & 就 & 442,625 & $1,282,469$ & 87,882 & 278,355 & 876,819 & $2,968,150$ \\
\hline & 指 数 & $103.8(15)$ & 104.1 (43) & $105.5(3)$ & $95.6(9)$ & $111.9(30)$ & $105.4(100)$ \\
\hline \multirow{5}{*}{52} & 生产㽬 & 370,747 & $1,189,020$ & 5,838 & 161 & 943,486 & $2,509,252$ \\
\hline & 輸此䊆 & 13 & 18 & 0 & 0 & 2,660 & 2,691 \\
\hline & 軨 又鼠 & 132,214 & 160,905 & 84,466 & 303,510 & 48,486 & 729,581 \\
\hline & 部 & 502,948 & $1,349,907$ & 90,304 & 303,671 & 989,312 & $3,236,142$ \\
\hline & 指 数 & $117.9(15)$ & $109.6(42)$ & $108.4(3)$ & $104.3(9)$ & $126.2(31)$ & $114.9(100)$ \\
\hline \multirow{5}{*}{53} & 生産量 & 405,654 & $1,323,737$ & 4,717 & 133 & $1,022,038$ & $2,756,277$ \\
\hline & 輸出量 & 9 & 2 & 0 & 0 & 2,683 & 2,694 \\
\hline & 輸 又㖏 & 146,319 & 155,156 & 99,606 & 249,416 & 65,731 & 716,228 \\
\hline & it & 551,964 & $1,478,891$ & 104,323 & 249,549 & $\mathrm{I}, 085,086$ & $3,469,813$ \\
\hline & 指 数 & $129.4(16)$ & $120.1(43)$ & $125.3(3)$ & $85.7(7)$ & $138.5(31)$ & $123.2(100)$ \\
\hline
\end{tabular}

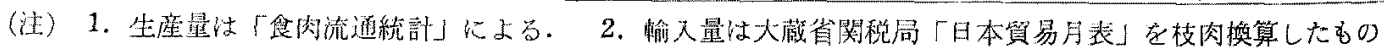

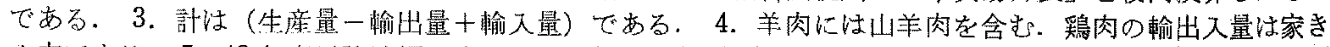

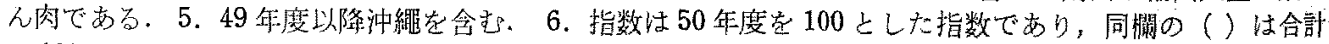

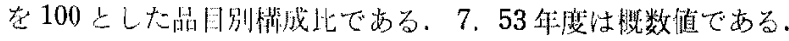


食肉の需縊に関する世界の動向

表 2. 国別㡏入数量")(1979 年：1～12月）

(トン)

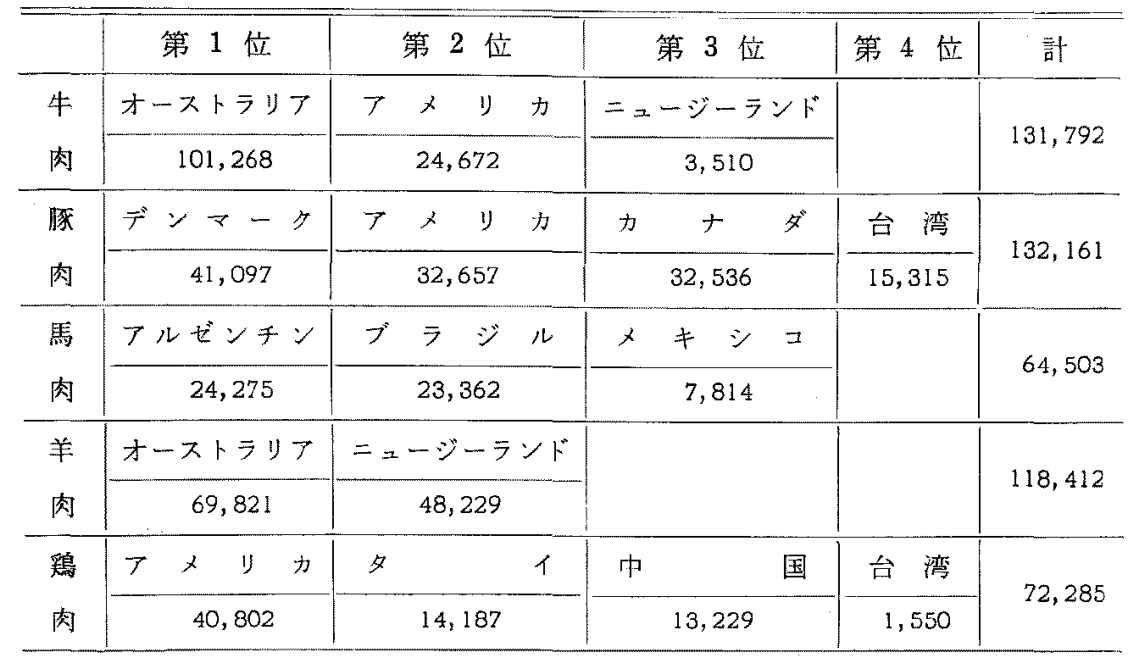

1）大蔵省「日本貿易月表」から引用. いずれも通関重量であるから，全体としては， 部分肉（骨好き）べース上考えて上い上思われる。

み店らず，わが国を部分肉の重要な輸出市場と考えてい る為である。

馬肉の約 70\% は，プラジルとדルゼンチンから輸入 されているが，いずれの国も，馬肉を重要な輸出物資と して位置づけ，牛や豚におけるがごとき再生産の体制を 整えているような兆しは認められていない，即占，現在 でも，ブラジルやアルゼンチンの自然牧野や山林汇半野 生状態で生息しているものを，捕獲して輸出に向けてい るのが寒情であるらしい。

羊肉については，豪州之ニュージーランドの二カ国 で，輸入量のほほ全量安占めている。しかも，この二カ 国で世界全体の翰出量の約 70\%をカパーしており，こ の二力国の羊肉の生産動向が世界の貿易量を左右すると いってい

鵎肉花主体とする家きえ肉の輸入量は，その約 70\%を 米国に依存し，他の国の追随定許さ始固な地位老確保 しているが，中国や夕䇚等も潜在的輸出意欲は強く，輸 出国としての地位は将来，益々高まってくるのではない かと考光られる。

わが国における最近の食肉需給動向と，その中で輸入 に徏存する部分については，主要な輸入相手国定，它れ ぞれの食肉別に概略を説明したが，これらの食肉の輸入 量のみ办らは，輸入それ自体の重要性と輸入をめぐる諸 問題の核心に触れること让治来ない。

わが国の食肉需給に占める輸入食肉の役割を理解し， しかも個々の輸入食肉が，我が国の需給にいがなる影響 を与えているかを知ることが，世界の食肉需給を俯甦す
るための基礎的条件となるに違いない．

\section{2. 輸入食肉の位置づけと輸入制度}

繰り返して云うが，食肉の需給表に示された個々の食 肉の輸入量，あるい性棇需要量以対寸る輸入量の割合加 らのみ，輸入食肉の重要性を判断することは危険であ る.輸入量は，あくまでも結果にすぎないといっても過 言ではあるまい。

即ち，輸入食肉飞関する分析を行う場合に前提上なる のは，第一にわが国の生産そのもの它めぐる諸問題を把 握すること，第二に，輸入食肉が，国産食肉とどのよう に競合しているかを把握すること，てして第三に，その 競合性を背景としていかなる輸入制度の下で個々の食肉 が輸入されているかを理解することではないかと考えら れるのである。

しかしながら，個々の食肉の生産伅関する諸問題を本 稿で説明することは，圥漫のそしりを免れないと思う し，多くの音産関係の雑誌等花通じて，既に会員諸兄の 理解されているとこるであるう。したがって，本稿で 性，輸入食肉の位置うけ（狭義には国産ものとの競合 甠）とそれぞれの輸入制度に触れておきたい。

\section{(1) 牛闪}

我か泪に輸入る物凟性，基本的に自由化 (AA) 品 目上末自由化品目に分類される。未自由化品目には，国 際競走力の弱い農産物が多く含まれているが，牛肉はそ の代表格といってよい，

牛肉结，榆入 (数量) 割当制度 (Import Quota: IQ 制 
度）の下で輸入される.即ち，1 年間に翰入する数量老 限定し，その籍囲内で輸入を伡可する制度である。

また日本の牛肉翰入割当制度は, 牛肉の佂格安定制度 とリンタしているところに大きな特徴がある. 即ち, わ が国の牛肉輸入の基本的な考え方整理すると，(1)国内 需要に刘し，国内生産では完全に充足できないので，そ の不足分を榆入方るここが建前ではあるものの，(2)牛肉 の輸入が，国産牛肉価格に悪影響を及ぼさな好上うに配 慮する方途上して, 総㡏入量の約 $90 \%$ 以相当する部分 の買い入孔と国内市場に対する放出住，畜産振與事業司 が行うことになっている.

したがって, わが国の牛肉翰入は, 国内の牛肉生産の 保諨，育成にとって，二重の安全弁，(輸入数量の規制 と放出数量の調整)を持っているということが出平る。

輸入されそ牛肉を事業付が売渡す場合の佂格は，国産 牛肉の洒格相当頻であるが, 輸入される牛肉の種類, 即 ち “高級牛肉 High Quality Beef”之称する琼物で肥育 した牛肉（主として米国，カナ名着）西るい性牧草のみ で肥育した牛肉 (主として豪州産)によって,それぞれが 国産牛肉のうち，どのクラス（乳用去勢牛や乳用皆牛の 「上」，「中」，「並」「等外」等の等級）に相当するか底 決めたうえで，最低壳渡し洒格を定姉り，入忙売り

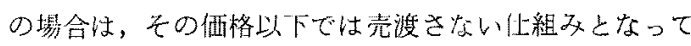
いるのである。

国産件肉の佂恪安定起図るため，和牛去勢牛の「中」

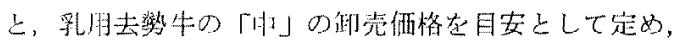
輸入する牛肉の種類（数物肥育牛, 牧草肥育牛, そして 高級，低級部位等）及び売渡す牛肉の種類を，それぞれ の競合性に基ういて畜産振興事業団が決定しているわけ であるが，榆入牛肉の大部分は国産の乳用種から生産さ れている牛闪との㜔合性が強いと考えられている。

輸入牛肉の用途は, 一口に大秝向けの需要を充足させ るといっても，その品質，部位，そして洒格によって非 常に多岐にわたる。例关济，豪州産の老廃倠牛の場合 は，一般の精肉店やスーパー等で販壳される挽き肉材料 となったり，ハンバーダやハンバーガーの原料, あるい はソーセージの原料として利用ざれる割合が大きいし， 米国産の款物肥育した牛のバラ肉等は，近年急激に伸長 した㸱树の材料となるといった具合である。

以上のことから判るようk，例えば㡏入牛肉の年䦌輸 入量が 10 万トンといっても，わが国の牛肉生産に与え る影響は，ての内容（㮔類，部位）によって極好大き な差があるということなのである，その意味で，米国産 の高級牛肉の愉入は, 和が国の牛肉生産にとって, 今後

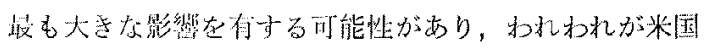

の牛肉生産を拄視せざるを得ない根拠となっているのて ある。

\section{(2) 豚肉}

豚肉は，輸入制度上は，完全に自由化されているとい えるが，これも牛肉と同様に，国内価格安安定させるた めの措置として，差額関税制度が寒施されている.

差額関税制度というのは，一ロで云元心゙，外国の豚肉 が，国内産豚肉上り安い価格では流通洁来ない仕組多で ある.即ち，これ以下の価格で愉入できないという俩 格を，基潐翰入価格」と称し，これが，每年 3 月末汇畜 透審議会の答申定受けて決定される主要市場における炀 枝肉「上」規格の安定上位洒格（昭和 55 年度: $764 \mathrm{M} /$ $\mathrm{kg}$ ) と安定基集価格（588 円 $/ \mathrm{kg}$ ) の中心価格（676 円/ $\mathrm{kg}$ ）と同価格に設定されている。一方，腧入される豚肉 の大部分は部分肉（枝肉から骨を除㫖し，主な部位に分 割したもの) の形状であるため，上記の 676 円 $/ \mathrm{kg}$ を， 部分肉の歩留 $(0.75)$ で除して，901 円 $/ \mathrm{kg}$ 基準輸入 価格として適用するのが一般的である。

わが国の関税制度では，唋入される豚肉の「CIF 佂格 （運賃，保険料込夕の榆入価格）の $8.8 \%$ 基淮輸入洒 格と CIF 洒格の差のいずれか大きい額」を関税として 徵收することとなっている.

具体的な例を示すと, CIF 価格が 810 円 $/ \mathrm{kg}$ であっ た場合，その $8.8 \%$ は，71.3 円 $/ \mathrm{kg}$ であり，基集輸入価 恪との差は (901 -810=91门) 91 円 $/ \mathrm{kg}$ であるから，関 税額は 91 円 $/ \mathrm{kg}$ となる。また, CIF 洒格多，840 円/

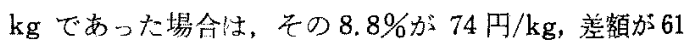
円 $/ \mathrm{kg}$ となるから，関税額は $74 \mathrm{~A} / \mathrm{kg}$ となる。

したがって，CIF 価格が 600 円 $/ \mathrm{kg}$ とか 700 円 $/ \mathrm{kg}$ 台の場合は，差額関税の額性当大きいのとなるの で，輸入業者は，関税額を極力小さくするため，定率関 税部分 $(8.8 \%)$ と差額部分が等しくなる洒格 (901\% $1,088 \doteqdot 828$ 円 $/ \mathrm{kg})$ を目安にして輸入しようと試みるわ けである。

例光ば，低級部位であるバラ肉の久定輸入した場合， CIF 価格はとても 828 円 $/ \mathrm{kg}$ というような高い価格に はならないし，逆に高級部位であるとレとロース代かり 輸入すれば，828 円 $/ \mathrm{kg}$ 超える CIF 洒格となる。そ己 で, ヒレ，ロース，モモ，カタ，バラの五つの部位を， 海外の相場悹勘案して, 適当に組多合和せ, 去の平均 CIF 洒恪が，828 円 $/ \mathrm{kg}$ 前後になるようにして輸入する ことが，現在では㡏入業者の常識になっている．

こうした組合わせによって輸入する場合，ここ数年の 傾向としては，全体の60８0\%程度がロースとヒレで 占められるとみてよいと考えられる。慗すれば，此较的 
高級（高価）な部位引シ，相対的に低い関税で輸入されて いるということになるのである。本来は，枝肉なべース にした榆入想定して作られた関税制度の盲点というこ とがいえよう.

このような豚肉榆入の実態に対しては, 最近では，生 産者側からの不满が大きくなっており，ロース，バラ， モモ及び力夕等，部分肉別に基準輸入洒格を設定すべき であるとの意見が顕在化している。

さてこのような組合わせが，単に関税の多寡のみを 意識して行われているのであろらか、答は否である。 かが国偷入される豚肉の最大の需要者は，八么，ソ 一セージ等の食内加工品製造業者であり，彼等が輸入す る豚肉の大部分が心ムやソーセージの原料として利用さ れている.これらの食肉加工品の生産量は，現在では年 間 40 万トンに達しているが，ここ数年間，特に生産の 伸びが著しいのが，ロースハム及びベーコンである，最 近恃，八ム，ン一セージの製造工程は大部分機㭜化され ているので，原料肉の品揃え，即亏，規格のそろったも のに対する需要は益々強くなっているのが現状である. そこで，大手の加工メーカ一等の中には，米国，力ナダ 及びデンマークの特定のパッカー（と畜，解体，部分闪 製造を一貫して行う業者）と契的を結び，自社の製造ラ インに適する規格のロースやバラ等の原料肉を輸入して いるものさえいるのである。

特に，ロース穵例にとると，わが国で年間に輸入する ロース住, 約700万加5800万頭分の豚加ら生産された 量に相当すると云われており，かが国で 1 年閶に上殺さ れる豚が，1,500 万頭であることを考えると，輸入され る豚肉のわが国の需要に対する位置づけがどの程度のも のか理解されよう。

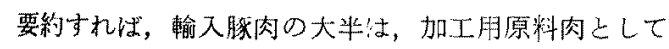

利用されており，現行の輸入制度上の利点（需要者に上 っての）上原料肉ししての品腯，䙺格の点での優位性に 基すいて，方方国の豚肉需給に大きな位置它占めるに至 ったということになるらか。

\section{(3) 羊肉及び馬肉}

羊肉及び馬肉恃，国内需要量の大部分定輸入に在し ていること前に述ベた。したがって，榆入制度につい ては，自由化品目であり，かつまたいずれの場合も絽税 である。

羊肉と馬肉の用途は，大部分加加工用原料であり，中

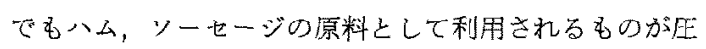
倒的に多い，么ム，ソーセージを一般に食肉加工品之総 称するが，これを二つのダループに分けて，需給動向を 云々することが多い。

即ち，豚肉のみ定原料とするロース八ムやベーニン 等を「筆味品」と呼んで一つのグループとし，残りを一 つのグループをする分け万である. 単味品以外のグルー プの代表格がプレスハム類，ウインナー及びフランクフ ルトソーセージ類である。これらの慗品は，豚肉と羊 肉，及び馬肉を主原料上する点が共通しており，年間的 40 万トン生産される食肉加工品のうち, プレスハムと ソーセージ類を合わ的 70\%を占めている. 生産量 の伸び率からいえば，巣味品の方が優位走保っている が，供給量について依然としてこれらの製品のウエイ トが藏い。

昭和 40 年代に入って，国民の食生活吕洋風化してき たといわれるが，ての一翼を柦ってきたのが，このプレ スハムとソーセージ類であるといって過言ではないと思 う.原料肉の確保しいう面で，極めて制約の多いわが国 の食肉生産事情の下で，海外では類をみ交い羊肉や馬肉

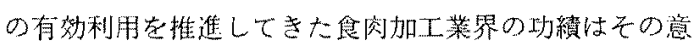

表 3, 食闪加工品生産量の推移

$(i v)$

\begin{tabular}{|c|c|c|c|c|c|}
\hline 年次 & ロ一ス八乙等 & ベーコン & ブレスハム等 & 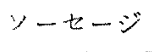 & 計 \\
\hline 35 & 4,866 & 2,223 & 29,310 & 37,801 & 74,200 \\
\hline 40 & 7,276 & 2,955 & 59,338 & 66,309 & 135,878 \\
\hline 45 & 15,930 & 6,520 & 101,160 & 105,840 & 229,450 \\
\hline 49 & 33,120 & 16,040 & 101,320 & 129,410 & 279,890 \\
\hline 50 & 34,242 & 16,934 & 103,650 & 143,092 & 297,924 \\
\hline 51 & 38,411 & 18,889 & 116,532 & 160,341 & 334,173 \\
\hline 52 & 49,575 & 24,507 & 126,894 & 177,876 & 378,852 \\
\hline 53 & 56,393 & 28,697 & 124,236 & 176,646 & 385,972 \\
\hline 54 年 & 71,076 & 33,727 & 114,587 & 179,695 & 399,085 \\
\hline
\end{tabular}

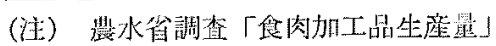


永 村

表 4. 牛の曆殺蒷数

$(1,000$ 䫑)

\begin{tabular}{|c|c|c|c|c|c|c|c|}
\hline $\begin{array}{l}\text { 地 } \\
\text { 域 }\end{array}$ & 国 & $\begin{array}{l}1971 \sim 75 \\
\text { 平 妁 }\end{array}$ & 1976 & 1977 & 1978 & $1979^{1)}$ & $1980^{2}$ \\
\hline \multirow{3}{*}{ 北 } & うち力 ナ ダ & 4,293 & 5,420 & 5,321 & 4,724 & 4,100 & 3,850 \\
\hline & $\neq \quad シ \quad \sqsupset$ & 4,359 & 5,400 & 5,731 & 6,200 & 6,100 & 6,200 \\
\hline & 米 & 32,829 & 48,726 & 48,073 & 44,272 & 37,000 & 35,500 \\
\hline 米 & 棓 & 43,219 & 61,561 & 61,254 & 57,539 & 49,640 & 48,166 \\
\hline \multirow{2}{*}{ 南 } & らちフルゼンチン & 10,311 & 13,868 & 14,748 & 16,449 & 15,300 & 14,500 \\
\hline & ブ & 10,680 & 11,300 & 12,500 & 11,200 & 10,650 & 10,400 \\
\hline 米 & 柿 & 28,111 & 33,669 & 35,257 & 35,922 & 34,196 & 33,581 \\
\hline \multirow{4}{*}{ 西 } & うちフ ラ ン ス & 7,566 & 8,092 & 7,563 & 7,496 & 7,959 & 8,317 \\
\hline & 西 & 5,234 & 5,416 & 5,237 & 5,316 & 5,640 & 5,400 \\
\hline & 英国 & 4,192 & 4,464 & 4,116 & 3,960 & 3,790 & 3,670 \\
\hline & E C 計 & 26,955 & 28,123 & 27,359 & 26,968 & 27,750 & 27,822 \\
\hline 欧 & 棓 & 33,055 & 34,326 & 33,344 & 32,878 & 33,695 & 33,755 \\
\hline \multirow{2}{*}{$\begin{array}{l}\text { 東 } \\
\text { 欧 }\end{array}$} & らちポーランド & 4,641 & 5,201 & 4,378 & 4,502 & 4,623 & 4,597 \\
\hline & 訊 & 8,612 & 9,719 & 8,776 & 7,456 & 9,238 & 9,153 \\
\hline & ソビ エ & 28,407 & 38,191 & 36,433 & 37,642 & 37,900 & 38,400 \\
\hline & フ フ リ カ & 3,476 & 3,246 & 3,353 & 3,635 & 3,860 & 3,810 \\
\hline \multirow{2}{*}{$T$} & jち1 ン ド & 1,673 & 1,711 & 1,723 & 1,737 & 1,750 & 1,780 \\
\hline & 韓 & 310 & 404 & 472 & 491 & 523 & 591 \\
\hline \multirow[t]{2}{*}{$\ddot{~}$} & $r \quad ル$ & 2,808 & 3,317 & 3,117 & 2,787 & 2,670 & 2,500 \\
\hline & 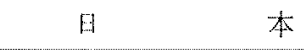 & 1,148 & 1,023 & {$[, 198$} & 1,263 & 1,240 & 1,260 \\
\hline$T$ & 鼓 & 7,536 & 8,171 & 8,533 & 8,478 & 7,238 & 7,232 \\
\hline \multirow{3}{*}{$\begin{array}{l}\text { オ } \\
セ \\
Y \\
= \\
T\end{array}$} & うちオーストラリア & 7,606 & 11,434 & 12,700 & 12,346 & 9,955 & 8,500 \\
\hline & 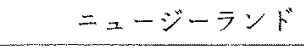 & 2,975 & 3,868 & 3,570 & 3,596 & 3,202 & 2,950 \\
\hline & 郬 & 10,581 & 15,302 & 16,270 & 15,942 & 13,157 & 11,450 \\
\hline & 総 & 162,997 & 204,185 & 203,220 & 199,492 & 188,924 & 185,547 \\
\hline
\end{tabular}

1) 整定梴 2) 予測值

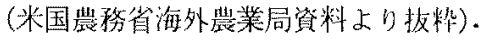

味で賞顔に值しょう。

ところか，この数力年の傾向として，これらの羊肉や 馬肉を主原料とした製品の需要が伸び悩えでいる一方 で，䀠肉を原料とした単味品は急激に伸長していること が指掂されている，即も，高級品に刘する嗜好が伸びて いることと，競合する食肉製昆の種類が多様化したこと あるいは多锺多様な外食産業の伸長がその背景にるるの ではないかということだ。

しかも，この倾向を助長する要因として，この数年 閒，豚肉の生産が過剩気味で，価格も比較的低位安定で 推侈していることと，需給のひっ迫による羊肉と零肉の
海外価格の高榺が挙げられよう。

したがって，業界にしては，今後羊肉及び馬肉主主原 料とした製品に対する需要がこれ以上伸びることはない とする見方が支配的になっているようだ。しかしなが ら，消費者の選好为らみた食品の需粭と離れて，安全保 障の観点からみた食料の確保という意味では，今まで築 いてきたオセアニア反び南米の羊肉及び馬肉資源の䊗入 上有效利用に関する框績を，長期的な視野からみて，ど の程度磪保すべきかという点を検討する余地は十分にあ るのではないかと思かれる。

(4) 芜き几肉 
食肉の需給に関する地界の動向

表 5 . 豚の屡殺頭数

( 1,000 䫑)

\begin{tabular}{|c|c|c|c|c|c|c|c|}
\hline \multirow{2}{*}{$\begin{array}{l}\text { 地 } \\
\text { 域 }\end{array}$} & \multirow{2}{*}{ 国 } & $1971 \sim 75$ & \multirow{2}{*}{1976} & \multirow{2}{*}{1977} & \multirow{2}{*}{1978} & \multirow{2}{*}{$1979^{11}$} & \multirow{2}{*}{$1980^{2)}$} \\
\hline & & 平均 & & & & & \\
\hline \multirow{2}{*}{ 北 } & 5ち力 & 10,235 & 8,969 & 9,077 & 10,027 & 12,100 & 12,800 \\
\hline & 米 & 82,480 & 74,959 & 78,442 & 78,417 & 90,240 & 95,400 \\
\hline 米 & 計 & 99,940 & 91,360 & 95,360 & 96,529 & 110,596 & 116,481 \\
\hline \multirow{2}{*}{$\begin{array}{l}\text { 南 } \\
\text { 米 }\end{array}$} & うちブ ラジル & 12,360 & 14,450 & 15,000 & 17,000 & 15,000 & 18,000 \\
\hline & 詃十 & 20,962 & 23,147 & 23,554 & 25,589 & $24,4.72$ & 27,618 \\
\hline \multirow{4}{*}{ 西 } & うち $\vec{\tau}^{*} \vee-\not$ & 11,238 & 10,604 & 11,064 & 12,068 & 13,400 & 14,300 \\
\hline & 西 独 & 31,374 & 32,901 & 34,450 & 36,254 & 37,700 & 37,500 \\
\hline & 才 & 10,010 & 10,987 & 11,439 & 12,530 & 13,000 & 13,200 \\
\hline & 英 & 14,828 & 13,498 & 14,196 & 13,764 & 14,647 & 14,100 \\
\hline \multirow{2}{*}{ 欧 } & E C & 101,784 & 104,504 & 109,315 & 114,522 & 120,717 & 120,870 \\
\hline & 部 & 125,145 & 130,817 & 137,567 & 144,462 & 151,908 & 153,364 \\
\hline \multirow{2}{*}{ 東 } & 5ち八ンガリー & 8,343 & 8,062 & 8,100 & 8,200 & 8,200 & 8,400 \\
\hline & ポーランド & 19,054 & 17,887 & 16,585 & 19,874 & 20,720 & 21,549 \\
\hline \multirow[t]{3}{*}{ 欧 } & 計 & 45,770 & 45,344 & 45,330 & 50,618 & 50,320 & 51,349 \\
\hline & ソ & 67,527 & 57,653 & 61,259 & 67,299 & 70,000 & 70,000 \\
\hline & ᄀ $>$ リ & 1,708 & 1,667 & 1,718 & 1,697 & 1,611 & 1,589 \\
\hline \multirow[t]{2}{*}{7} & 弓古台 & 4,804 & 5,482 & 6,141 & 6,100 & 6,300 & 6,200 \\
\hline & 国 & 1,820 & 2,293 & 2,350 & 3,010 & 3,941 & 3,781 \\
\hline \multirow{2}{*}{$\begin{array}{l}\ddot{*} \\
7\end{array}$} & 本 & 14,029 & 14,277 & 16,075 & 17,439 & 19,200 & 20,500 \\
\hline & 計 & 30,139 & 32,461 & 33,567 & 36,991 & 41,423 & 43,473 \\
\hline \multirow{2}{*}{$\begin{array}{l}\text { オ7 } \\
セ= \\
7\end{array}$} & らちオーストラリア & 3,950 & 3,384 & 3,589 & 3,637 & 3,560 & 3,850 \\
\hline & 計 & 4,744 & 4,105 & 4,415 & 4,440 & 4,284 & 4,580 \\
\hline & 計 & $395,93.5$ & 385,554 & 402,770 & 427,625 & 454,614 & 468,454 \\
\hline
\end{tabular}

1) 暫定値 2) 予測值

(米国農務省海外農業局資料上り拔䊉).

家きん肉といっても，その大部分は鷄肉を意味してい る.輸入制度としては，全て自由化品目であるが，適用 される税率が品目により若干異なる。

即ち，鵴肉のうち，「骨つきモも肉」は，関税率が $17.5 \%$ (今次「東京ラウンド」で関税率の引下げに合意: 1987 年に 10\%になるように段階的に引下げることにな ったであり，それ以外のものは，20\%の関税が課せら れる。主た，七面鳥の肉は，10\%の税率が適用されてい る.

わが国が，昭和 54 年 1 12月に輸入した家きん闪江 72,285 トンであったが，うち鷭肉が 70,071 トンであっ た.したがって，輸入される家きん肉の殆ど全てが鷄肉 と多て差支党ない。
輸入される鷭肉安大別すると「冒つきモモ」,「正肉」， 「丸どり」，「その他」の4つに分類される。昭和 54 年

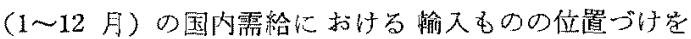
輸入比率で示すと次のようになる。

(1)正肉」の輸入比率 $=14,000$ トン $/ 417,000$ トン $\div 3.4 \%$ (2)骨つきも无」の川 $=42,000 / 69,200 \quad \doteqdot 60.7 \%$ (3) 丸どり」の" $=7,000 / 29,000 \quad \doteqdot 24.1 \%$

これ虫，主要業界莸対象とした調査加ら推定した値で あるが，特に(2)「骨つきモモ」及び「丸どり」の輸入 が，国内生産に対して強い影䇾老有していることが判る 5 .

当然のことながらこれらの輸入品の流通洒格は，国産 物の佂恪と比較してかなり低く，「骨つきモモ」では約 
永 村

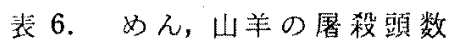

$(1,000$ 揭)

\begin{tabular}{|c|c|c|c|c|c|c|c|}
\hline $\begin{array}{l}\text { 地 } \\
\text { 域 }\end{array}$ & 国 & $\begin{array}{l}1971 \sim 75 \\
\text { 平 均 }\end{array}$ & 1976 & 1977 & 1978 & $1979^{11}$ & $\left.1980^{3}\right)$ \\
\hline \multirow{3}{*}{$\begin{array}{l}\text { 北 } \\
\text { 米 }\end{array}$} & 5类来国 & 9,680 & 6,911 & 6,555 & 5,543 & 5,175 & 5,225 \\
\hline & x $\neq$ y $=$ & 4,967 & 4,210 & 4,900 & 4,900 & 4,800 & 4,750 \\
\hline & 部 & 15,137 & 11,555 & 11,785 & 10,708 & 10,233 & 10,250 \\
\hline \multirow{3}{*}{$\begin{array}{l}\text { 献 } \\
\text { 米 }\end{array}$} & うちアルゼンチン & 7,889 & 8,098 & 8,295 & 8,168 & 8,200 & 8,100 \\
\hline & ブ & 4,220 & 4,600 & 4,100 & 3,550 & 3,800 & 3,800 \\
\hline & 合計 & 22,246 & 21,605 & 20,365 & 20,372 & 20,282 & 21,260 \\
\hline \multirow{3}{*}{ 西 } & うちフ & 7,589 & 8,465 & 8,273 & 8,522 & 9,194 & 9,500 \\
\hline & 英 国 & 12,095 & 12,672 & 11,364 & 11,616 & 11,250 & 11,750 \\
\hline & $\mathrm{EC}$ & 29,021 & 30,519 & 28,801 & 29,702 & 29,835 & 30,775 \\
\hline \multirow{3}{*}{ 欧 } & jbキا リ & 10,653 & 11,475 & 11,190 & 11,182 & 11,171 & 11,170 \\
\hline & ス ペ 1 บ & 12,961 & 12,743 & 12,754 & 12,433 & 11,400 & 11,650 \\
\hline & 計 & 55,760 & 58,413 & 56,617 & 57,239 & 56,424 & 57,663 \\
\hline \multirow{2}{*}{$\begin{array}{l}\text { 東 } \\
\text { 欧 }\end{array}$} & うちューゴスラビフ & 5,197 & 5,312 & 4,000 & 5,149 & $5, \infty 00$ & 5,300 \\
\hline & 合 & 6,315 & 6,128 & 4,700 & 6,116 & 6,024 & 6,300 \\
\hline \multirow{4}{*}{$\begin{array}{l}7 \\
7 \\
y \\
7\end{array}$} & ソビ $ェ ト$ & 61,547 & 55,137 & 55,371 & 56,000 & 56,500 & 56,500 \\
\hline & 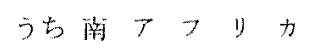 & 9,229 & 10,136 & 9,950 & 10,686 & 11,214 & 11,080 \\
\hline & $E F \geqslant I$ & 5,190 & 4,720 & 5,040 & 5,250 & 5,000 & 5,250 \\
\hline & $\overrightarrow{\bar{a}} \mid$ & 14,419 & 14,856 & 14,990 & 15,936 & 16,214 & 16,330 \\
\hline \multirow{4}{*}{$\begin{array}{l}7 \\
\ddot{r} \\
T\end{array}$} & 号1 y & 38,831 & 39,792 & 40,107 & 40,458 & 40,600 & 41,500 \\
\hline & $1 \quad \overline{7}$ & 14,456 & 20,000 & 20,000 & 20,000 & 21,000 & 19,000 \\
\hline & $r \quad$ u $=$ & 27,207 & 30,217 & 27,621 & 25,494 & 24,600 & 23,900 \\
\hline & 計 & 81,247 & 90,769 & 88,503 & 86,731 & 86,988 & 85,174 \\
\hline \multirow{4}{*}{$\begin{array}{l}\text { オ } \\
\text { 七 } \\
\nearrow \\
\bar{\gamma} \\
\end{array}$} & 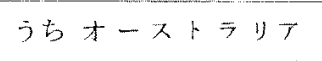 & 37,399 & 33,655 & 30,503 & 27,472 & 29,000 & 29,680 \\
\hline & 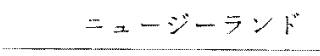 & 34,825 & 32,630 & 32,403 & 34,100 & 33,496 & 35,020 \\
\hline & 尌 & 72,225 & 66,285 & 62,906 & 61,572 & 62,496 & 64,700 \\
\hline & 総 & 328,895 & 324,748 & 315,237 & 314,674 & 315,161 & 318,177 \\
\hline
\end{tabular}

1) 整定值 2) 手測值

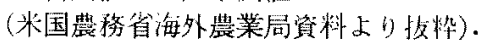

200 円 $/ \mathrm{kg}$ の洒格差があるといわれているが，襄条返せ ば，輸入物と国産物の末端需要の性格が異なるというこ

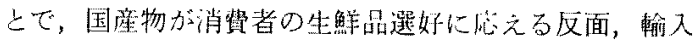
物は支価であることに活路を求めているといら一種の措 存䦥保があるといえなくもない。

しかしながら，最近の冷・解凍技術の進步仿めざし

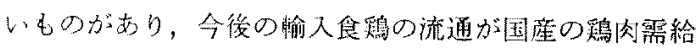
に正え影響は，強まるこ上はあっても，隇少すること

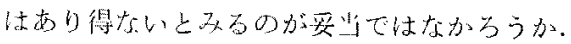

以上,「牛肉」,「豚肉」,「羊肉」,「馬肉」及び「貌肉」

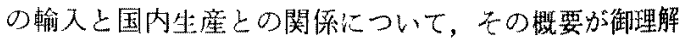
いただけたものと思う、これを踏まえたうえで，本題の 世界の食肉需給の動向に入ろうと思う。

\section{3. 食肉に関する世界の需給勤向}

この锺の統計值については,FAO，米国農務省USDA， 及び経济協力開発機構 OECD のものが一般に用いられ ている. 


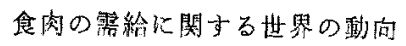

表 7. 需 9 屠殺頭数

(1, 000 頭)

\begin{tabular}{|c|c|c|c|c|c|c|c|}
\hline $\begin{array}{l}\text { 地 } \\
\text { 域 }\end{array}$ & 国 & $\begin{array}{l}1971 \sim 75 \\
\text { 平 均 }\end{array}$ & 1976 & 1977 & 1978 & 19791 & $1980^{2 !}$ \\
\hline \multirow{2}{*}{$\begin{array}{l}\text { 贷 } \\
\text { 米 }\end{array}$} & $5 b x \neq=1$ & 188 & 140 & 130 & 130 & 130 & 130 \\
\hline & 誩户 & 188 & 140 & 130 & 130 & 130 & 130 \\
\hline \multirow{3}{*}{$\begin{array}{l}\text { 南 } \\
\text { 米 }\end{array}$} & うちてルゼンチン & 277 & 215 & 245 & 280 & 290 & 270 \\
\hline & ブラジル & 567 & 560 & 392 & 510 & 500 & 500 \\
\hline & 計 & 877 & 803 & 670 & 829 & 834 & 814 \\
\hline \multirow{3}{*}{ 西 } & 5ちフ & 171 & 159 & 154 & 148 & 141 & 134 \\
\hline & 1 & 266 & 282 & 278 & 287 & 287 & 290 \\
\hline & $\mathrm{EC}$ 棓 & 482 & 498 & 499 & 500 & 497 & 494 \\
\hline \multirow{2}{*}{ 欧 } & うちスペイイン & 87 & 31 & 30 & 33 & 30 & 30 \\
\hline & 計 & 601 & 612 & 613 & 609 & 601 & 594 \\
\hline \multirow{2}{*}{$\begin{array}{l}\text { 東 } \\
\text { 欧 }\end{array}$} & 占ポーランド & 133 & 70 & 78 & 72 & 74 & 73 \\
\hline & 計 & 137 & 73 & 80 & 74 & 76 & 75 \\
\hline \multirow{2}{*}{$\begin{array}{l}\overline{7} \\
7 \\
\text { J } \\
力 \\
\end{array}$} & 5b乇 & 34 & 21 & 24 & 24 & 25 & 25 \\
\hline & 合 & 34 & 21 & 24 & 24 & 25 & 25 \\
\hline \multirow{2}{*}{$\begin{array}{l}T \\
\forall \\
T\end{array}$} & 万立小 & \multirow{2}{*}{$\ldots$} & \multirow[b]{2}{*}{69} & 45 & 48 & 35 & 40 \\
\hline & 合 & & & 70 & 71 & 56 & 60 \\
\hline & 総 & 1,914 & 1,718 & 1,587 & 1,737 & 1,722 & 1,698 \\
\hline
\end{tabular}

1) 暫定值 2) 予測值

(米国農務省海外農業局)資料より挍精).

FAO は，最近 1985 年の辳産物の需給見通しを公表し ている。これは，国際食糧農業協会から邦訳版が既に出 版されているので，本稿では割愛しようと思う。

米国農㹣省からは，定期的に（月下仿多い）各種の刊 行物が発刊されてふり，鼠近時の世界の食肉需給を知る うえで最も有益な情報といえる。

特に，今年 2 月に公表した世界の食肉需給の 1980 年 見通しは，この㮔の情報の中でる罠新のものといえるの で, その概要と需給に関する主要な諸統計值当紹介して 拉きたい。

この報告は，世界の38力国を新乘としているが，走 ず家畜の頭数について要約すると。

牛の飼養頭数は，主要生産国では同調的周期性があ り, 米国では1979年を底として1980 年に僅汃に堌加に 転じ，カナダも同倳の傾向にあるすのの，象州，二=ジーランド及びフルゼンチンでは前年に引続き隇少し た. 交た、ブラジルは 1977 年から牛群の拡大が認めら れる一方，世界の牛肉市場の影慇をあまり強く受けない
インドや EC 諸国では，安定的に推移している。また， ソ連では 1977 年以降，年率 $1 \%$ の，そして東欧諸国は $0.5 \%$ 增加率を亦している。

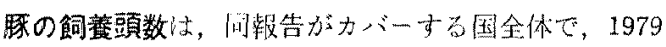
年1月加51980年1月の䦌，3\%の増加を东た。なる れは, 1976 年以降継続的に增加基調にある。

めん羊の飼看頭数は，1977年に最低を記録したが，

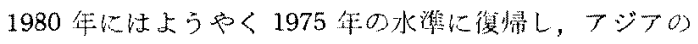

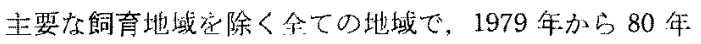
にかけて增加した。

山羊の飼養頭数は，始ど変化がないるのと推定される

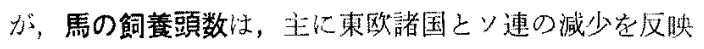
して，全体としては減少した。

次に，家畜のと殺頭数について姕的宁ると，牛の屠殺

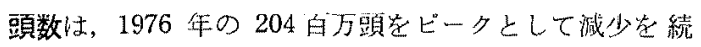
け，1980年には187百万頙になると見逼され，特に米 国，カナダ，フルゼンチン，蒙州等の生座に強い周期性 のある国々での減少が目立っている（表 4 参照） 
永 村

表 8. 牛肉生産量”

$(1,000 \vdash v)$

\begin{tabular}{|c|c|c|c|c|c|c|c|}
\hline 地 & 名 & $1971 \sim 75$ & 1976 & 1977 & 1978 & 10709 & \\
\hline 域 & 픠 & 平均 & 200 & t5 & 1070 & 107 & $1500^{\circ}$ \\
\hline \multirow{3}{*}{ 北 } & らち力 ナが & 936 & 1,162 & 1,143 & 1,060 & 955 & 910 \\
\hline & $\neq \quad:$ & 730 & 918 & 974 & 1,054 & 1,037 & 1,054 \\
\hline & 国 & 8,255 & 12,166 & 11,845 & 11,283 & 9,932 & 9,616 \\
\hline 米 & 計 & 10,242 & 14,620 & 14,345 & 13,822 & 12,372 & 12,063 \\
\hline \multirow{3}{*}{ 南 } & らちてルゼンチン & 2,188 & 2,811 & 2,914 & 3,193 & 2,990 & 2,880 \\
\hline & ブ ラジル & 2,109 & 2,230 & 2,450 & 2,200 & 2,100 & 2,050 \\
\hline & ウ $ル$ グ & 308 & 405 & 363 & 354 & 268 & 306 \\
\hline 米 & 計 & 5,600 & 6,628 & 6,888 & 6,949 & 6,611 & 6,543 \\
\hline \multirow{3}{*}{ 晒 } & 5ちフランス & 1,613 & 1,799 & 1,652 & 1,658 & 1,791 & 1,880 \\
\hline & 独 & 1,309 & 1,414 & 1,383 & 1,435 & 1,520 & 1,500 \\
\hline & 国 & 1,006 & 1,069 & 1,032 & 1,048 & 1,010 & 980 \\
\hline \multirow{2}{*}{ 欧 } & $\mathrm{E} \mathrm{C}$ & 6,074 & 6,540 & 6,398 & 6,420 & 6,642 & 6,700 \\
\hline & 訪 & 7,248 & 7,816 & 7,660 & 7,657 & 7,901 & 7,952 \\
\hline \multirow{2}{*}{$\begin{array}{l}\text { 東 } \\
\text { 欧 }\end{array}$} & うちポー ランド & 602 & 806 & 717 & 709 & 733 & 746 \\
\hline & 計 & 1,760 & 2,133 & 2,007 & 2,025 & 2,067 & 2,088 \\
\hline & \% ビ $x ト$ & 5,578 & 6,152 & 6,406 & 6,590 & 6,510 & 6,510 \\
\hline & フ フ リ 力 & 607 & 588 & 619 & 665 & 701 & 695 \\
\hline \multirow{2}{*}{$T$} & 5古 1 & 184 & 188 & 189 & 191 & 192 & 196 \\
\hline & 韓 & 51 & 75 & 104 & 108 & 115 & 130 \\
\hline \multirow[t]{2}{*}{$\ddot{~}$} & ル & 178 & 180 & 199 & 163 & 158 & 155 \\
\hline & 本 & 301 & 298 & 361 & 403 & 405 & 412 \\
\hline 7 & 計 & 921 & 946 & 1,082 & 1,119 & 1,031 & 1,059 \\
\hline \multirow{3}{*}{$\begin{array}{l}\text { J } \\
t \\
T \\
\bar{T} \\
\bar{T}\end{array}$} & 方九一ストラリ7 & 1,372 & 1,899 & 2,149 & 2,134 & 1,794 & 1,570 \\
\hline & 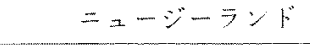 & 432 & 628 & 557 & 549 & 491 & 465 \\
\hline & 計 & 1,805 & 2,527 & 2,707 & 2,682 & 2,285 & 2,035 \\
\hline & 計 & 33,760 & 41,411 & 41,714 & 41,509 & 39,477 & 38,944 \\
\hline
\end{tabular}

1) 枝肉べース 2) 整定値 3) 予测值

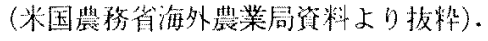

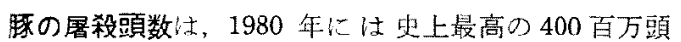
に達すると見通され，米国とブシジルの增加がそれに畐 献している。（表 5 参㫛）

めん山羊の屠殺頭数は，1979 年より全体として䄪 $1 \%$ の增加が見通されるが，票州とニュージーランドでは $0.5 \%$ 増にとどまる。（表 6 参照）

食肉の生産量について要的方当と,

牛肉の生産量は, 1979 年の水淮少占約 50 万卜ン減少

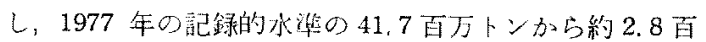
万トン減少した水澌となる。地域别に久ると，北米，南
米及びオセアニアで减少し，西欧，東欧及びソ連を除く アジア諸国でやや増加する。ソ連の牛肉生産量は, 平均 枝肉重量の低下により，屠殺頭数の增加にも加加わらず 減少するものと見通される。（表 8 参照）

㨀肉の生産量は，ソ連を除く殆ぞの国で堌加する。(表 9 参照)

めん山羊肉の生産量は，全体で䄪 $1 \%$ 增加しよう。 （表 10 参照）

次に，俵肉の貿易について要約すると，

赤肉（牛, 滕, めん山羊及び馬肉）の貿易量恃, 生産 
食肉の需給に関する世界の動问

表9. 豚肉生産量1

$(1,000$ 頭 $)$

\begin{tabular}{|c|c|c|c|c|c|c|c|}
\hline 地。 & 用 & $1971 \sim 75$ & 1976 & 1077 & & $1070 ?$ & \\
\hline 域 & 口 & 平均 & 1970 & 1977 & 1978 & $1979^{27}$ & $1980^{\circ}$ \\
\hline 丮 & j力 & 615 & 533 & 539 & 620 & 745 & 785 \\
\hline & 米 & 6,329 & 5,755 & 6,009 & 6,075 & 7,035 & 7,425 \\
\hline 米 & 計 & 2,393 & 6,771 & 7,061 & 7,222 & 8,322 & 8,756 \\
\hline 苚 & らちブ ラ ジ ル & 683 & 785 & 834 & 850 & 850 & 1,000 \\
\hline 米 & 計 & 1,228 & 1,354 & 1,404 & 1,415 & 1,473 & 1,627 \\
\hline & 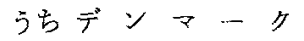 & 756 & 716 & 744 & 812 & 915 & 975 \\
\hline 西 & 独 & 2,349 & 2,423 & 2,483 & 2,618 & 2,730 & 2,710 \\
\hline & $\bar{Y} タ ゙ *$ & 788 & 889 & 914 & 993 & 1,040 & 1,060 \\
\hline & 英 & 980 & 807 & 869 & 848 & 900 & 870 \\
\hline 欧 & $\mathrm{E} \mathrm{C}$ & 7,657 & 7,849 & 8,152 & 8,604 & 9,067 & 9,100 \\
\hline & 計 & 9,420 & 9,819 & 10,269 & 10,820 & 11,380 & 11,504 \\
\hline 東 & らちハンガリー & 429 & 416 & 461 & 465 & 470 & 480 \\
\hline & ポーランド & 1,382 & 1,543 & 1,548 & 1,766 & 1,842 & 1,967 \\
\hline 欧 & 計 & 3,581 & 4,125 & 4,237 & 4,552 & 4,520 & 4,664 \\
\hline & ソ ピエ & 3,792 & 3,053 & 3,480 & 3,727 & 3,656 & 3,515 \\
\hline & $\begin{array}{lll}\nearrow & \text { フ }\end{array}$ & 87 & 84 & 86 & 85 & 82 & 81 \\
\hline $\bar{\gamma}$ & 5 台台 & 394 & 457 & 510 & 510 & 527 & 519 \\
\hline & 韓 & 91 & 98 & 141 & 172 & 205 & 208 \\
\hline シ & 日 & 939 & 1,056 & 1,169 & 1,284 & 1,400 & 1,500 \\
\hline$T$ & 計 & 1,832 & 2,006 & 2,183 & 2,359 & 2,584 & 2,717 \\
\hline 木二 & 方オースト リア & 197 & 179 & 192 & 199 & 204 & 220 \\
\hline$T$ & 訫 & 234 & 212 & 235 & 241 & 242 & 259 \\
\hline & 総 & 27,567 & 27,423 & 28,956 & 30,423 & 32,260 & 33,122 \\
\hline
\end{tabular}

1）枝肉ベース 2) 整定值 3) 予测値

(米国農等省海外㻃業局資料上り拔粋)。

量の約 $9 \%$ となるが，畜種によりその比洎は異なり，牛 肉では 10\%，豚肉で蛙 7\%，めん山羊肉では $18 \% ， 飞$ して馬肉の場合は生産量の約 $2 / 3$ に達する。（表 $11 ， 12$, $13,14,15$ 参照)

なかでる，米国，EC 諸国，及びソビエトの牛肉輸入 蚛增加するものの，アルゼンチン・オセアニア及び西欧 諸国の輸出量は減少するので，貿易の需給はややひっ迫 するであろう。

一方，EC 諸国，及び乘欧諸国からの豚肉の輸比洁 干增加すると見通されるものの，輸入量全体仙大きな変 化がないと考えられるので，いくつかの国で認められる 腦肉の增産は，趣終的に国内消費に吸収されることとな
ろう.

羊肉の貿易量については, 79 年と殆ど变化はないるの と考光られるが, 才セアニアからの輸出量がやや增加 (ソ連むけのマトン，イランむけのラム)するであるう。

馬肉に対する需要は，フランス，ベルギー，イタリア 及び日本などて，依然として强いものと考えられる。

おわりに，芜きえ肉の生産と貿易についての 1980 年 の見通しを総括すると次のとおりである。

まず，家きん肉の生産量は，全体て $4 \%$ 增加し，その 5ち鴊肉は 5\%, 七面鳥は 10\%程度伸びる.米国は, 鵎

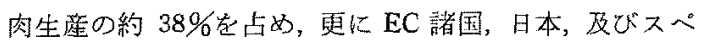
インの合計で約 30\%上なる。面鳥では罵闪以上に生 
永 村

表 $10 . \infty$, 山羊肉生产量1

$(1,000 ト ン)$

\begin{tabular}{|c|c|c|c|c|c|c|c|}
\hline $\begin{array}{l}\text { 此 } \\
\text { 戟 }\end{array}$ & 国 & $\begin{array}{l}1971 \sim 75 \\
\text { 平 圽 }\end{array}$ & 1976 & 1977 & 1978 & $\left.1979^{2}\right)$ & $1980^{88}$ \\
\hline \multirow{3}{*}{$\begin{array}{l}\text { 北 } \\
\text { 米 }\end{array}$} & j米国 & 256 & 168 & 159 & 140 & 133 & 134 \\
\hline & $x+y \quad 1$ & 56 & 56 & 55 & 55 & 53 & 52 \\
\hline & 合棓 & 291 & 232 & 220 & 200 & 191 & 191 \\
\hline & らちフルゼンチン & 134 & 127 & 132 & 130 & 132 & 130 \\
\hline & 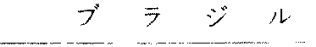 & 56 & 58 & 51 & 44 & 48 & 48 \\
\hline 来 & 合＼cjkstart計 & 325 & 303 & 288 & 288 & 288 & 295 \\
\hline \multirow{3}{*}{ 西 } & うちフ ラ ソ ス & 135 & 155 & 154 & 157 & 169 & 175 \\
\hline & 英 & 240 & 248 & 229 & 238 & 225 & 239 \\
\hline & E C & 502 & 538 & 516 & 535 & 529 & 550 \\
\hline \multirow{3}{*}{ 欧 } & うちギリ シ ア & 102 & 117 & 119 & 119 & 119 & 119 \\
\hline & x & 144 & 146 & 144 & 142 & 125 & 130 \\
\hline & 合 & 796 & 850 & 831 & 848 & 828 & 855 \\
\hline \multirow{2}{*}{$\begin{array}{l}\text { 東 } \\
\text { 欧 }\end{array}$} & う口゙ーコスラビず & 50 & 60 & 57 & 62 & 61 & 63 \\
\hline & 部门 & 185 & 201 & 192 & 194 & 195 & 199 \\
\hline \multirow{4}{*}{$\begin{array}{l}7 \\
7 \\
\text { if } \\
\text { 力 }\end{array}$} & ソ ビ $ェ ト$ & 924 & 841 & 849 & 875 & 855 & 855 \\
\hline & うち垶てフリカ & 146 & 161 & 164 & 176 & 174 & 175 \\
\hline & モ & 52 & 54 & 57 & 59 & 55 & 59 \\
\hline & 合 & 198 & 215 & 221 & 235 & 229 & 234 \\
\hline \multirow{2}{*}{$T$} & 551 & 366 & 358 & 359 & 364 & 370 & 380 \\
\hline & 1 & 233 & 380 & 383 & 377 & 390 & 350 \\
\hline \multirow{2}{*}{$\begin{array}{l}シ ゙ \\
\ni\end{array}$} & ル & 347 & 384 & 352 & 326 & 318 & 309 \\
\hline & 計 & 956 & 1,134 & 1,105 & 1,079 & 1,090 & 1,051 \\
\hline \multirow{3}{*}{$\begin{array}{l}J \\
t \\
⿱ 乛 \\
= \\
\bar{T}\end{array}$} & ら方九ーストラリ丁 & 672 & 592 & 538 & 492 & 522 & 533 \\
\hline & ニュージーラソド & 537 & 513 & 498 & 498 & 486 & 530 \\
\hline & 䚵 & 1,209 & 1,105 & 1,035 & 990 & 1,008 & 1,063 \\
\hline & 郭 & 4,882 & 4,879 & 4,743 & 4,709 & 4,684 & 4,741 \\
\hline
\end{tabular}

1) 枝肉ベース 2) 急定值 3) 予測倠

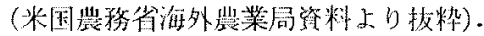

産加特定国飞集中し，生産量全体の57\%老米国，乙して 30\%を EC 諸国が占好る。(表 16 参照)

家きん肉の貿易（輸出）黾は，EC，米国及びハンガリ 一の三つで但界の大部分老担っており，1979年の輸候量 約 111 万トンのうち，51\%が EC，21\%が米国，をして 10\%をハンガリーが占好た。但し，EC の非出量の $2 / 3$ は，EC 域内に当けら机ている。(装17参照)

以上が，米国農䈷省に上る 1980 年の食肉需給の見通 しであるが，これ在幾分補足するために，OECDの1980
年以降の短期見通しから，要点なピックフップしてみる と, 以下のとおりである。

まず，1980年以降の短期見通しを行う場合に念頭にお くべき点として，次の事柄を指摘している.

(1) 北米及びオセア二フ諸国の肉牛生産者の意識が今 後の牛群の拡大と牛肉の生㡾にどの程度の影響を持つの か.

(2) 牛肉生産の減少とその他の食肉の生産增加，そし て牛肉に対する需要の軟化が，北米及びオセアニフの牛 
食肉の需維に䦔する世界の動向

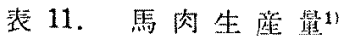

$(1,000$ ト $)$

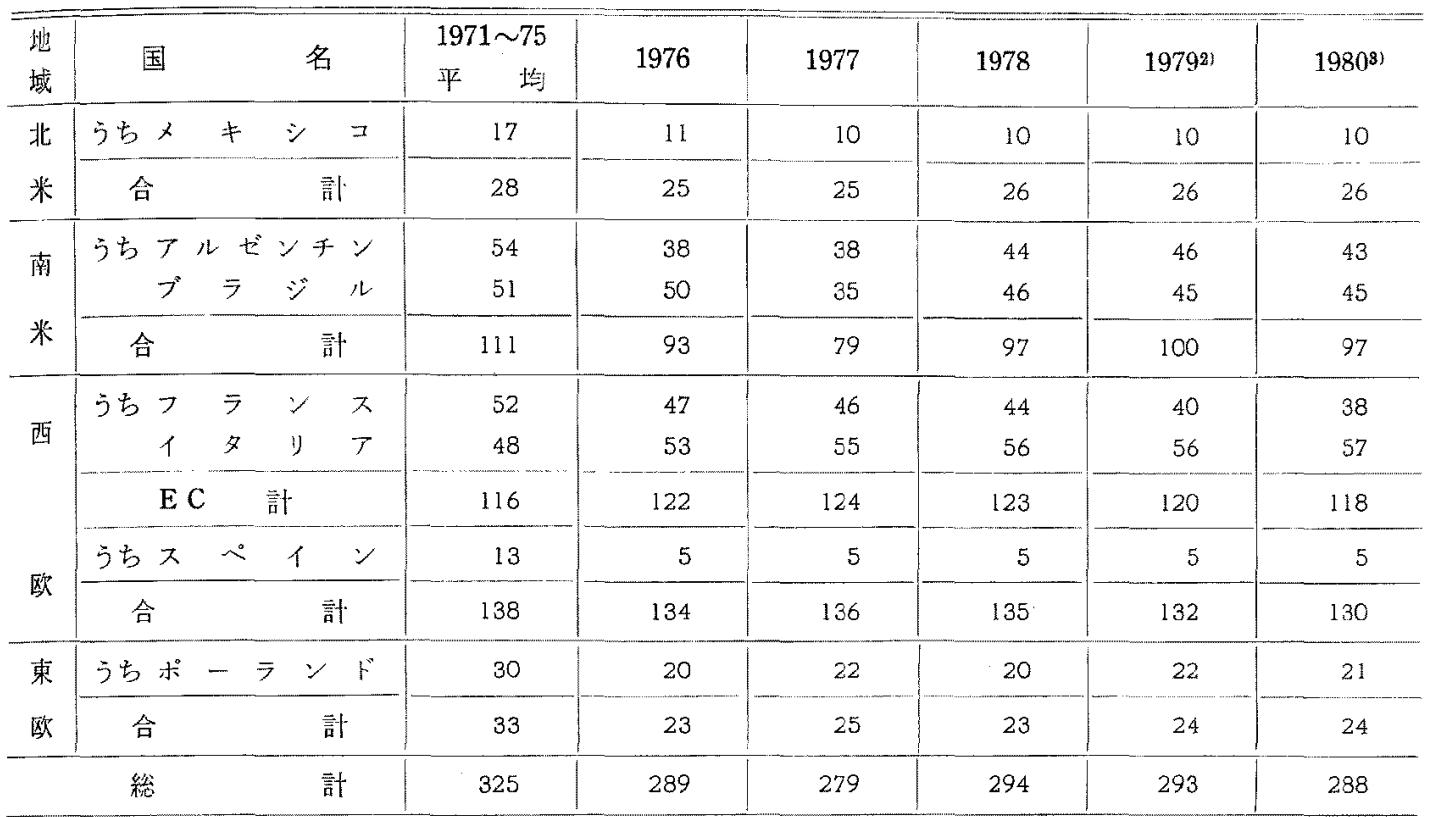

1) 枝肉ベース 2) 整定值 3) 予測值

(米国農務省海外農業局䐝料より拔粋).

肉相場によ゙の程度のインパクトを持つか。

(3) 豪州に扔ける早鬿の程度と，これが牛群及び辛群 の飼養に与える影響の大きさ。

(4) 飼料作物の生産量と価格が畜産に与える影響.

(5) 最近の高金利が家畜の生産と食肉貿易に与える影

響.

(6) EEC 諸国の繁殖雌牛頭数がやや減少した理由と その順向が持続寸るか否か。 また, 1980 年に, 繁殖膯群 の規模が桩大する可能性.

(7) 日本の乳用雌牛頭数削减計画の結果とその削減頭 数に見合う肉用雌牛群の桩大があったか否か，文の結果 が日本の牛肉生産に与元る影響は?

(8) 日本の豚肉生曆が今後に゙の程度まで搪大するか。 豚肉の需給の不均衡（供給過剩）加，牛肉の消筫上羊肉 の輸入にどのような影響があるか。

(9) 羊肉と羊毛価格の見通しに最も重要な影嘅を与之元 る要因法何分。最近の牛肉相場の不安定性，一部の輸入 市場の不安定性，及び経済情勢の全般的悪化等が羊肉及 び羊毛価格の低下菬来する上考えてよいか，更に，そ の洒格の低下が豪州上ニュージーランドの羊群拡大の蔽 どめとなり得るか否か。

以上の事柄を念頭化置きつつ，最近の食肉篅給の動向 分析すると，

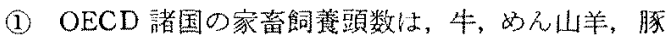

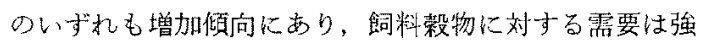
まっているので，トゥモロコシ及び大豆を始めをする飼 料穀物は記録的な増产にもか加わらず，価格法 1979 年 以降上昇索続けている。

(2)牛闪生産の維少により貿易量子縮少し，国際洒格 は上昇した。但し，牛肉価格は上昇したといらものの，

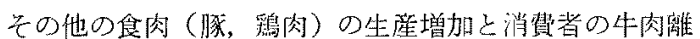
机により，牛肉㑑格の上㫒には限界があった。东た，1979 年の高金利は，牛肉の質易にかなりのマイナスの影響を 与之た。 1980 81 年の $\mathrm{OECD}$ 諸国の牛肉生産は，牛群 規模の㕬大を伴いつつ減少定続けるもの上見通される が，之の場合でも，(a)世界全体の経济事情と牛肉需要に

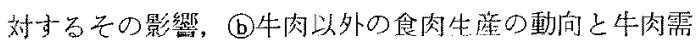
要に対す万その影響，(飼料亮物の生産と伍格の動向

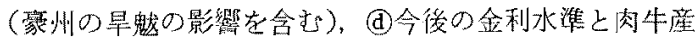
業に沶ける投資に対寸る影響. 等が不安定要因として存 在する。

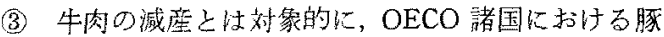
肉及代羊肉の生産性, 1979 年から80 年にが增加し た。しかし，豚闪ひ增加率は現代念游化低下している。 EEC と日本，そして北米と日本の間の成肉貿易量は增 加しているが，牛肉の貿易と比校すると豚肉上羊肉の重 
永 村

裴 12. 牛肉の貿易量

$(1,000$ ト $)$

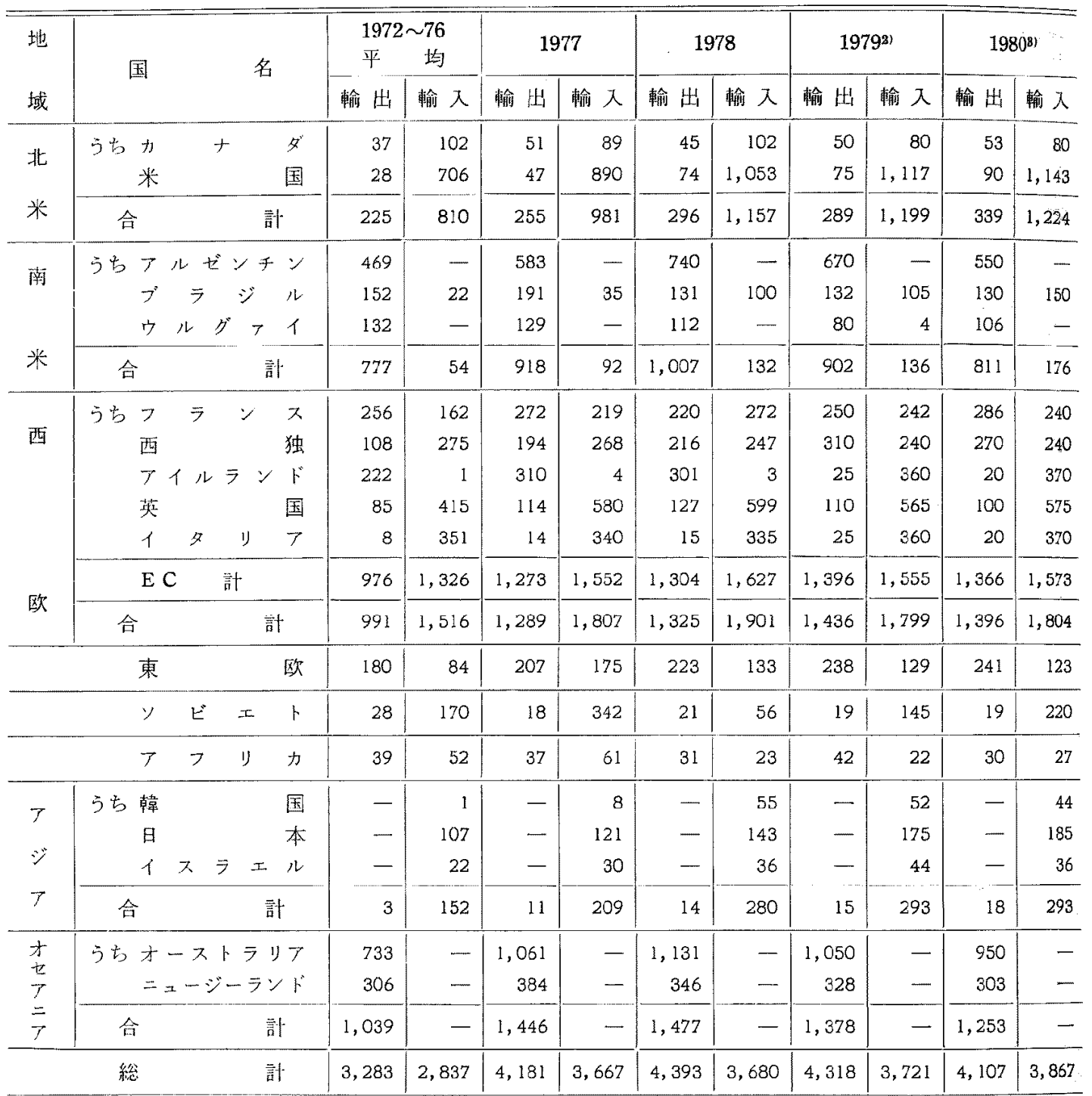

1) 枝肉一ース, 但し，生音は除く 2) 暫定值 3) 予測湖

(米国農務省海外農業局資料より抜粋).

要性は小さい，但し，豚肉の增産がその他の食肉の貿易 に与えた影響は大きく，中でも，回米国における胼肉の 増産名北米の牛肉価恪の及ならず国際佂格に対してもマ イナスの影響安与えたこと、及び，日本の豚肉生産の堌 加が，加工用原料の，羊肉から豚肉へのシフト助長し た結果，日本の拝肉輸入量が激減したこと、は特篗に值 $す る$.

一方, 羊肉と羊毛の価格は高位で安定しているため, 豪州とニュージーランドの羊群拡大は現在むな打持続し
ているが，EEC，中柬，ソ連及び日本の羊肉需要をめぐる 不安定要因の存在と，経済事情の全般的退潮傾向が羊毛 需要に与える貨の影響を勘案すると，楽観的な見通しは 特にない、ということである。

以上，米国農務省と OECD の最近における世界の食 肉需給の見通しについて説明を加えてみたが，これによ って，各国の食肉生虐とそれぞれの食肉に対する需要 が，世界の貿易量に密接な関連究持っていることが理解 されたことと思う。ここで, 生産と需要及ご貿易との関 
食肉の需給に関する世界の動向

表 13. 脜肉の貿易量"

$(1,000$ トン $)$

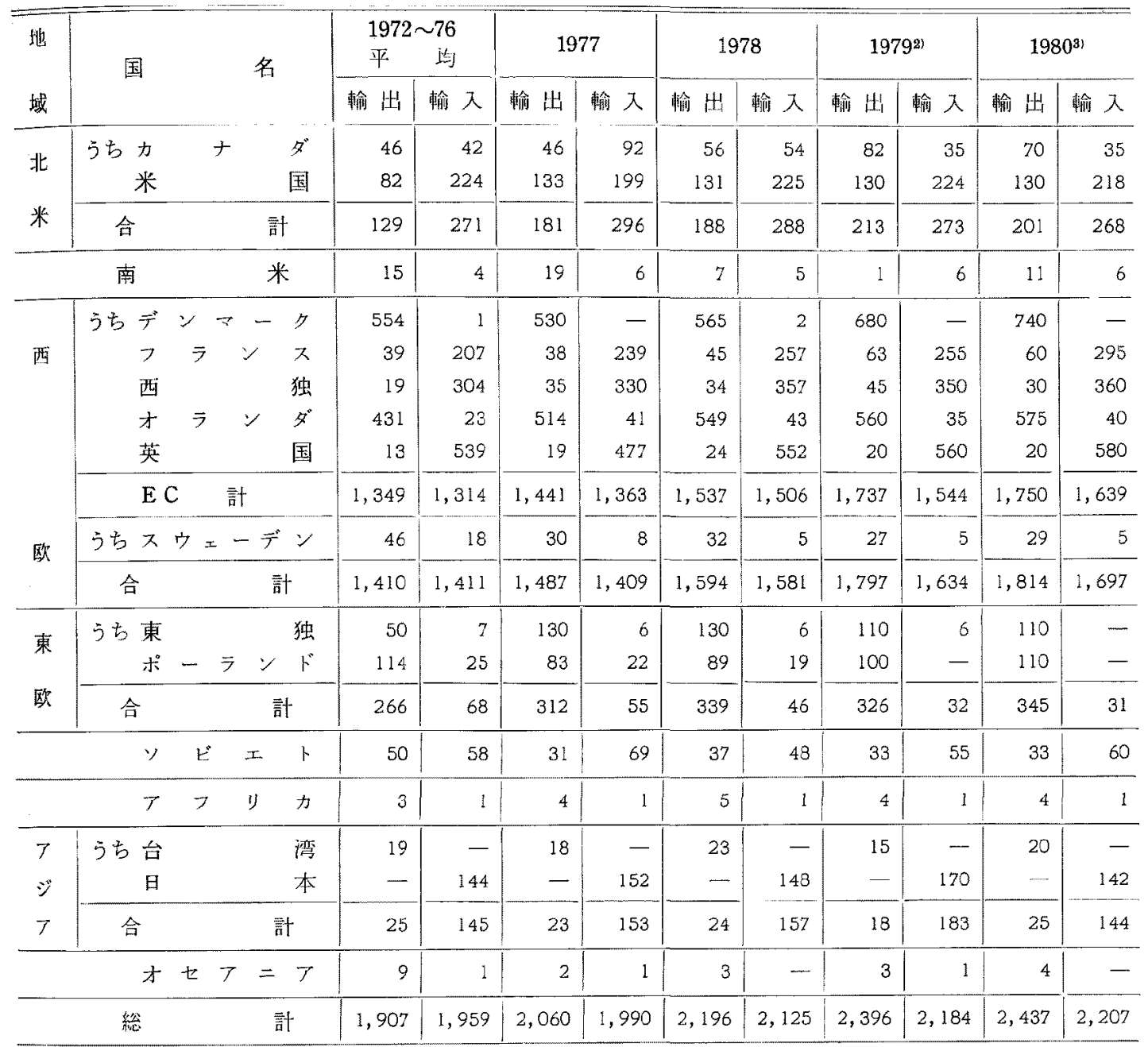

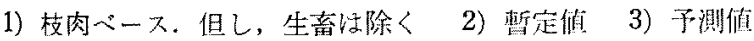

(米国農務省海外農業局資料より拔粋)。

係学，単純な模式図で示してみると図 1.のようになる う.この図式と今までの説明定踏ま元て，今後のわが国 の食肉需給の動向と世界の食肉需給の動问との相互関係 について述べよう。

\section{4. わが国の食肉需給と世界の食肉需給 との相互関係}

わ加国の食肉需給艺中心に，これと関連する諸国の動 きについて，その概要を説明する。

(1) 4 肉

わ加国の，今年度の牛肉生産は，乵用去攀牛の生産回 復と乳用睢牛の淘汰の継穘（低能力牛淘汰促進事業）に
より，乳用棰部門からの生産は前年度を上回ると想さ 扎るものの，和牛部門からの枝肉供給については，前年 並みの水準にとどまると見通しており，牛肉全体として は, 前年度亡同程度加, やや上回る程度 (40 41 万トン: 枝肉べース) となるら。

一方，牛肉の需要性，最近の等気後退や，豚肉価格の 低位安定を反映して，伸び悩えでいる，但し，業務加工 用需要は，ほぼ侹来通りの伸び走示寸ものと考元られる ので，全体の需要量的 60 万トン程度となるう，ての 結果，年間の牛闪輸入量は前年度並の水潐と考えてよい 乙思引。

一方，輸出国側の情淏は極好て流動的な要素索はらん 
永 树

表14。元，山羊肉の貿易量1

$(1,000$ ト $)$

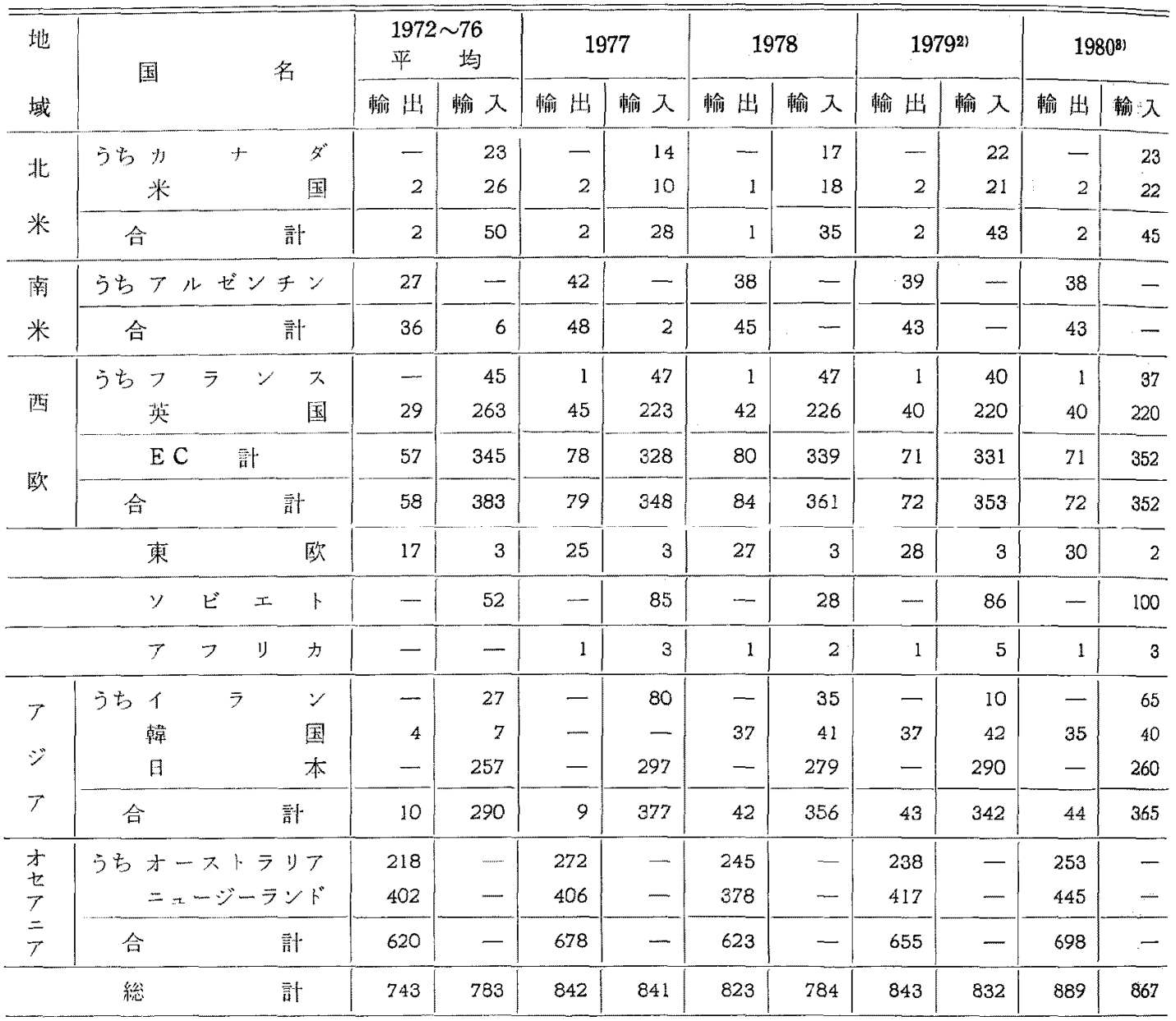

1）枝肉べース，生畜を除く 2) 暫定值 3）予測值

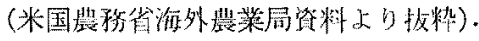

でいる。

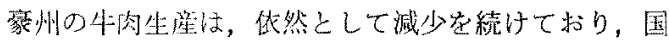
内の小売価格も高滕しているため，1 人当り牛肉消整量

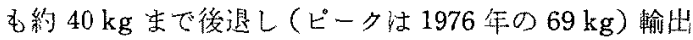
可能量も前年より 10 万トン減少して 91 万トン程度と見 通される。实た，今年初頭に豪州の南東部に広がった早 兔の被害は，大巾店牛肉生㯆にまで至らず，現在では小 康状態堂保っている。

一方，米国の牛肉生産も牛群の規模拡大伴いつつも 減産を続けて扔り，80 年も昨年より $2 \sim 4 \%$ 減少上見 込末れている，そのため，1978〜79年に牛肉の佂恪は 暴腾したため消費量も激減し，年間 1 人当りの牛肉提取 量は，79 年はついに $50 \mathrm{~kg}$ 台学割远九だ.この傾向は， 豚肉の增産（79 年：16\%增. 80 年：5 6\%增）及び鷄
肉と七面鳥つ增産（79 年：10\%,80 年： $5 \%$ 前後), 更 には米国経済全体覆う不景気及びインフレが拍車学か けているものである.（1980 年の消損者物㑡指数の上昇 来は約 $12 \%$ 已推定されている)，こうした牛肉消費の激 減が原因となって，最近で法かなりの大手パッカー（屠 音業者)が倒産する等の情報も流仿されておう，とれ

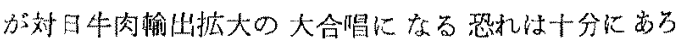
う.

いずれにしても，多少の榆出プレッシャーがこれらの 国タから一封的にかかるとしても，基本的にはこの1 2 年㤝，牛肉輸入に対する大きな攻勢はないるのと教光 てょいと思う。

(2) 豚肉

わが国の最近の豚肉需給の不均衡は周知のとおりであ 
食肉の需給飞関する怙界の動向

表 15 . 馬肉の貿易量

(1, 000トン)

\begin{tabular}{|c|c|c|c|c|c|c|c|c|c|c|c|}
\hline 地 & 周 & $\begin{array}{l}1972 \\
\text { 平 }\end{array}$ & $\begin{array}{r}76 \\
\text { 药 }\end{array}$ & & & & & & & & \\
\hline 域 & & 輸出 & 輸 入 & 軨 出 & 榆 入 & 榆 出 & 輸人 & 銣出 & 輸 $入$ & 輸 如 & 輤入 \\
\hline 北 & $+\quad \not ゙$ & 13 & - & 15 & $\longrightarrow$ & 16 & - & 15 & 一 & 16 & 一 \\
\hline & 米 & 30 & 3 & 54 & - & 55 & 一 & 54 & - & 54 & - \\
\hline 米 & 計 & 50 & 3 & 72 & - & 73 & 一 & 73 & - & 73 & - \\
\hline 南 & う⿱千口゙ルゼンチン & 47 & - & 38 & - & 44 & - & 46 & - & 43 & - \\
\hline & ブ & 50 & - & 35 & - & 42 & - & 41 & - & 41 & - \\
\hline 米 & 計 & 98 & - & 74 & - & 87 & - & 88 & - & 85 & - \\
\hline 西 & うちフ ラン ス & 1 & 40 & $:$ & 52 & 1 & 54 & 1 & 58 & 1 & 60 \\
\hline & オ $\overline{\text { オ } ン ~ タ ゙ ~}$ & 2 & 35 & 7 & 41 & 8 & 42 & 6 & 40 & 5 & 41 \\
\hline & $\mathrm{E} \mathrm{C}$ & 11 & 115 & 24 & 140 & 24 & 144 & 22 & 146 & 21 & 150 \\
\hline 欧 & 合 & 14 & 123 & 25 & 145 & 26 & 149 & 23 & 152 & 22 & 156 \\
\hline & 東 & 12 & - & 16 & - & 16 & - & 18 & - & 18 & $-\cdots$ \\
\hline 7 & う古日本 & 一 & 79 & 一 & 80 & - & 96 & - & 92 & - & 95 \\
\hline 7 & 合 & 4 & 79 & 2 & 80 & 3 & 96 & 2 & 92 & 2 & 95 \\
\hline & 総 & 177 & 204 & 189 & 225 & 205 & 245 & 203 & 244 & 200 & 256 \\
\hline
\end{tabular}

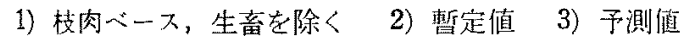

4）米国の輸出量は，馬肉以外のものを含むが，大

部分性馬肉と推定さ机るので一括して示されている。

(米国農務省海外農業局資料上り拔粋).

り，豚肉の輸入がこれに拍車をがけてる一つの要因て あること証否定出来ない。

わが国に䀢肉を輸出しているデンマーク，米国，力ナ ダ及び台湾等でも今までのとこるいずれも增産基調が続 いているが，米国では繁殖豚の淘汰が進み，現時点では 前年の水準以下の頭数になったことが指摘されたり，台
湾の上うに屠殺禁止といら強㹴な豚肉生産抑制を実施し たため，現在では価格が暴腾している等，今年の主要国 の豚肉生座は極めて流動的である。

わが国の加工業界も一定量の買いつけは従来通的行う ま口上しながらも，今年秋以降の国産豚肉の俩格低落在 必至上見ておう，昨年の輸入突績（正肉心゙ースで 13 万

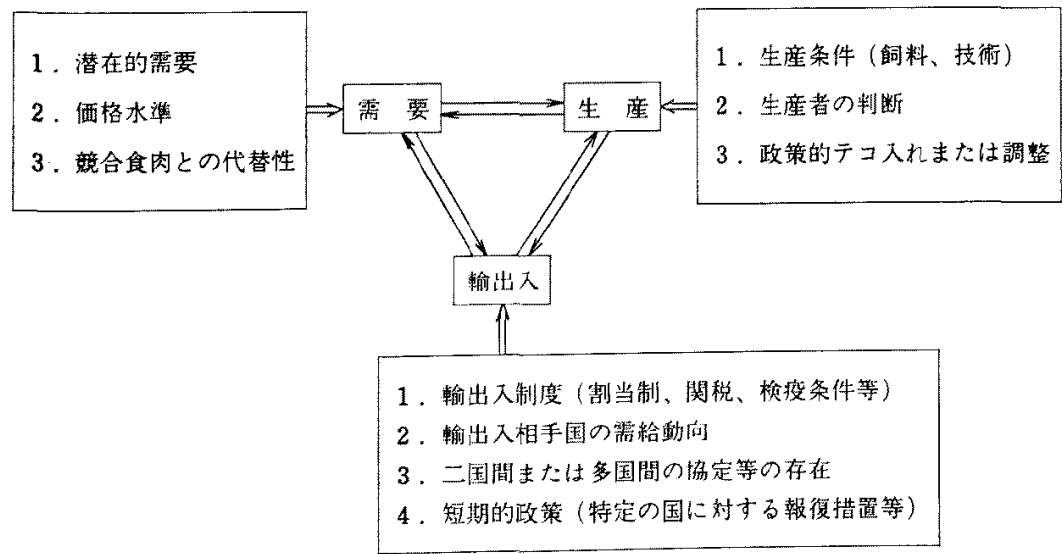

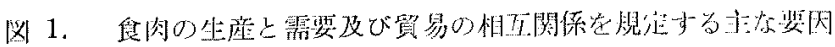


表 16 . 家き几肉の生産量

$(1,000+\vartheta)$

\begin{tabular}{|c|c|c|c|c|c|c|c|}
\hline 地 & 同 & $1971 \sim 75$ & 1976 & 1977 & $1978^{1)}$ & 19792) & $\left.1980^{8}\right)$ \\
\hline 域 & - & 均 & & & & & \\
\hline \multirow{2}{*}{ 北 } & 号力 & 447 & 458 & 461 & 484 & 539 & 523 \\
\hline & 米 & 4,855 & 5,385 & 5,535 & 5,895 & 6,507 & 6,874 \\
\hline * & 合 & - & 6,191 & 6,349 & 6,752 & 7,472 & 7,879 \\
\hline \multirow{2}{*}{ 南 } & らちフルゼンチン & 281 & 208 & 194 & 181 & 193 & 210 \\
\hline & ブ ラ ジ ル & 389 & 604 & 698 & 858 & 1,027 & 1,227 \\
\hline 米 & 合 & 863 & 1,108 & 1,206 & 1,315 & 1,512 & 1,740 \\
\hline \multirow{4}{*}{ 酉 } & 5⿱ 7 ラ & 764 & 865 & 902 & 963 & 1,013 & 1,038 \\
\hline & $\begin{array}{llll}1 & 8 & 1\end{array}$ & 815 & 851 & 864 & 897 & 925 & 945 \\
\hline & 英 & 638 & 732 & 763 & 783 & 818 & 848 \\
\hline & E C 計 & 3,052 & 3,348 & 3,464 & 3,591 & 3,734 & 3,817 \\
\hline \multirow[t]{2}{*}{ 欧 } & うちスペ イ ン & 582 & 695 & 735 & 755 & 785 & 815 \\
\hline & 計 & 3,918 & 4,383 & 4,564 & 4,735 & 4,926 & 5,068 \\
\hline \multirow{2}{*}{$\begin{array}{l}\text { 東 } \\
\text { 欧 }\end{array}$} & 5ち八ンガリー & 240 & 291 & 315 & 332 & 335 & 315 \\
\hline & 計 & 1,136 & 1,463 & 1,625 & 1,915 & 2,053 & 2,133 \\
\hline & ソ & 1,254 & 1,400 & 1,700 & 1,900 & 2,100 & 2,000 \\
\hline & 苚てフリカ & 163 & 258 & 276 & 279 & 283 & 291 \\
\hline \multirow{4}{*}{$\begin{array}{l}\gamma \\
\forall \\
\nearrow \\
\text { 等 }\end{array}$} & らちイス & 111 & 146 & 152 & 141 & 152 & 156 \\
\hline & オーストラリフ & 175 & 207 & 219 & 246 & 270 & 308 \\
\hline & 日 本 & 676 & 839 & 923 & 1,027 & 1,108 & 1,161 \\
\hline & 計 & 1,078 & 1,308 & 1,419 & 1,549 & 1,673 & 1,772 \\
\hline & 総 & - & 16,111 & 17,139 & 18,445 & 20,019 & 20,863 \\
\hline
\end{tabular}

1) 修正值 2) 暫定值 3) 予測值

(米国㟽務省海外農業局餈料より报粋).

トン）加らは大巾に減少し，今年は 10 万トン内外の輸 入量と見迅えでいるようだ.

(3) マトン及び馬肉

基本的に㰡て，これらの肉の輸入量家增加させる要因 は見当らない，国内需要の動向からみてもマトンと馬肉 の使用量は減るであらうし，ソ連や中柬諸国の買いつけ む昨年同様実施されると胃远まれるので現地相場が下が るとも思充ない。

(4) 索学肉

米国を除く軨入相手国の生産は殆ど縮少される傾向に あるので，輸入量が大りに增加することはないと考えら れる。
以上，極めて大ざっぱなわが国と世界の食肉需給の相 互関係と今年の榆入見通しを説明したが，ここで重ねて 強調したいのは，此界の食肉需給の勳向が，わが国の食 肉需給に年々強い影䅧を与えつつあるということだ。

農林水産省としては，昭和 65 年芝目標とした農産物 の中期需給見通し最近公表しているが，ての中で一定 の自給率の向上进唱いつつも，不足分安外国加の翰入 に依存せざるを得ないるのとしている。

その意味でも，国内の食肉生産，特化牛肉及び豚肉生 産技術の向上，流通の合理化等に加えて，広く世界㹸 野を厇げる必要性定痛感する，会員諸兄の内広い御支援 をいただきたいことを念じて篗を置きたい。 
食肉の需給に関する世界の動问

表 17。家き九肉の需給 (1979 年) ${ }^{11} \quad(1,000$ トン)

\begin{tabular}{|c|c|c|c|c|c|}
\hline $\begin{array}{l}\text { 地 } \\
\text { 域 }\end{array}$ & 国 & 生産量 & 輸入 墨 & 輸出量 & 消費量 \\
\hline \multirow{2}{*}{ 北 } & うち力 ナ ダ & 539 & 36 & 2 & 550 \\
\hline & 米 & 6,507 & - & 228 & 6,232 \\
\hline 米 & 計 & 7,472 & - & - & 7,215 \\
\hline \multirow{2}{*}{ 南 } & 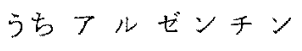 & 193 & 8 & - & 202 \\
\hline & ブ ラ シ ル & 1,027 & - & 70 & 957 \\
\hline 米 & 合 & 1,512 & - & - & 1,476 \\
\hline \multirow{4}{*}{ 西 } & らちフ ラン ス & 1,013 & 22 & 156 & 870 \\
\hline & タ 117 & 925 & 14 & 3 & 936 \\
\hline & 英 & 818 & 25 & 44 & 793 \\
\hline & E C 計 & 3,734 & - & 565 & 3,542 \\
\hline \multirow{2}{*}{ 欧 } & 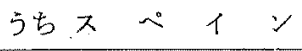 & 785 & 16 & 3 & 798 \\
\hline & 合 & 4,926 & - & - & 4,782 \\
\hline \multirow[t]{2}{*}{ 東 } & らちハンガリー & 335 & - & 115 & 220 \\
\hline & 合 & 2,053 & - & - & 1,895 \\
\hline & ソ ビ エ & 2,100 & 100 & & 2,200 \\
\hline & 南 フ フカ & 283 & - & - & 251 \\
\hline \multirow{4}{*}{$\begin{array}{l}T \\
\forall \\
T \\
T \\
\text { 等 }\end{array}$} & 5ち ス & 152 & 2 & 30 & 124 \\
\hline & オーストラリフ & 270 & - & 8 & 264 \\
\hline & 日 本 & 1,108 & 87 & 3 & 1,172 \\
\hline & 計 & 1,655 & - & - & 1,733 \\
\hline
\end{tabular}

1)推定值である.

(米国農務省海外農業局資料より拨粉). 